\title{
PENGARUH PEMBELAJARAN SAINTIFIK MODEL PROBLEM BASED LEARNING (PBL) DAN PROJECT BASED LEARNING (PJBL) TERHADAP HASIL BELAJAR MAHASISWA JURUSAN PGSD UNIPA SURABAYA PADA POKOK BAHASAN HAM
}

\author{
Atnuri ${ }^{1}$, Danang Prastyo ${ }^{2}$ \\ ${ }^{1,2}$ Pendidikan Guru Sekolah Dasar Universitas PGRI Adi Buana Surabaya \\ email: atnuri.sh.gmail.com ${ }^{1}$, danang_pgsd@yahoo.com ${ }^{2}$
}

\begin{abstract}
Abstrak
Penelitian ini bertujuan untuk mengetahui pengaruh pembelajaran Saintifik Model Problem Based Learning (PBL) dan Project Based Learning (PjBL) terhadap hasil belajar mahasiswa Jurusan PGSD Unipa Surabaya pada pokok bahasan HAM.Pengambilan sampel dilakukan dengan teknik random sampling. Populasi penelitian ini adalah mahasiswa PGSD Unipa Surabaya. Sedangkan sampel penelitian ini adalah mahasiswa angkatan 2014 yang terdiri dari tiga kelas, yaitu kelas A,B dan C. Validitas yang digunakan adalah validasi isi dan konstruk. Reliabilitas dalam penelitian ini diuji dengan menggunakan teknik KR-20. Analisis data dilakukan dengan bantuan program statistik SPSS versi 17 for windows. Dari analisis data penelitian diperoleh ada perbedaan hasil belajar antara model PBL dengan PjBL, hal ini dapat dilihat dari hasil signifikasi sebesar 0.035. Artinya, pada penelitian ini hipotesis diterima dengan asumsi Ho ditolak dan Ha diterima. Jadi dapat disimpulkan ada pengaruh perbedaan hasil belajar mahasiswa Jurusan PGSD Unipa Surabaya dengan menggunakan pembelajaran Saintifik Model Problem Based Learning (PBL) dengan Project Based Learning (PjBL) pada pokok bahasan HAM.
\end{abstract}

Kata Kunci: Problem Based Learning (PBL), Project Based Learning (PjBL), Hasil Belajar

\section{PENDAHULUAN}

Berkembangnya pendekatan pembelajaran menuntut seorang pendidik atau dosen untuk dapat menyesuaikan dengan perubahannya. Banyak pendekatan pembelajaran yang diterapkan dalam proses belajar mengajar (PBM), mulai dari pendekatan berbasis kepada siswa atau mahasiswa sampai pada pendekatan pembelajaran saintifik.

Sebagai Lembaga Pendidik dan Tenaga Kependidikan (LPTK), Universitas PGRI Adi Buana Surabaya mempunyai andil besar dalam mencetak tenaga guru yang professional. Diharapkan lulusan Universitas PGRI Adi Buana mempunyai jiwa kompeten, unggul, dan berkarakter serta mampu bersaing di era pendidikan saat ini dan masa yang akan datang. Untuk mewujudkan itu maka perlu adanya proses pembelajaran yang baik dan bermutu sesuai dengan visi dan misi Adi Buana Surabaya.

Proses pembelajaran yang baik dan bermutu dapat diwujudkan dengan pendekatan saintifik. Pendekatan saintifik merupakan proses pembelajaran yang dirancang agar peserta didik mampu untuk menemukan informasi melalui tahapan-tahapan yaitu mengamati, menanya, mencoba atau mengumpulkan, mengasosiasi atau menalar, dan mengomunikasikan. Namun, pada kenyataannya belum semua kegiatan pembelajaran di perguruan tinggi menggunakan pendekatan saintifik hal ini disebabkan karena banyak faktor salah satunya adalah kekurangpahaman dan kemalasan seorang dosen dalam menerapkan pembelajaran saintifik di kelas 
Dosen yang handal adalah seorang pendidik yang mampu mengaplikasikan pendekatan saintifik kedalam pembelajarannya. Banyak manfaat yang diperoleh mahasiswa jika dosen menerapkan pembelajaran saintifik, salah satunya adalah meningkatkan daya kritis dan kreasi mahasiswa. Mahasiswa akan tertantang untuk belajar menyelesaikan masalahnya dengan kemampuan dan bimbingan dari dosen. Selain itu mahasiswa akan termotivasi untuk terus belajar dan menggali semua informasi untuk menyelesaikan masalah yang dihadapinya.

Berawal dari manfaat yang diperolah dari pembelajaran saintifik, peneliti berusaha meneliti Pengaruh Pembelajaran Saintifik Model Problem Based Learning (PBL) dan Project Based Learning (PjBL) Terhadap Hasil Belajar Mahasiswa Jurusan PGSD Unipa Surabaya Pada Pokok Bahasan HAM.

\section{PEMBAHASAN}

Pendekatan Saintifik

Menurut Hosman (2014: 34)

Pendekatan saintifik adalah proses pembelajaran yang dirancang sedemikian rupa agar peserta didik secara aktif mengonstruk konsep, hukum atau prinsip melalui tahapan-tahapan mengamati (untuk mengidentifikasi atau menemukan masalah), merumuskan masalah, mengajukan atau merumuskan hipotesis, mengumpulkan data dengan berbagai teknik, menganalisis data, menarik kesimpulan dan mengkomunikasikan konsep, hukum atau prinsip yang ditemukan.

Sementara itu berdasarkan teori Dyer (dalam Sani, 2014:53) dapat dikembangkan pendekatan saintifik dalam pembelajaran yang memiliki komponen proses pembelajaran antara lain: mengamati, menanya, mencoba atau mengumpulkan informasi, menalar atau membentuk pertanyaan (melakukan komunikasi.

\section{Karakteristik Pembelajaran dengan pendekatan Saintifik.}

Menurut Hosnan (2014:36)

pembelajaran dengan metode saintifik memiliki karakteristik sebagai berikut:

a. Berpusat pada siswa.

b. Melibatkan keterampilan proses sains dalam mengonstruksi konsep, hukum atau prinsip.

c. Melibatkan proses-proses kognitif yang potensial dalam merangsang perkembangan intelek, khususnya keterampilan berpikir tingkat tinggi siswa.

d. Dapat mengembangkan karakter siswa.

\section{Tujuan Pembelajaran dengan Pendekatan Saintifik}

Tujuan pembelajaran dengan pendekatan saintifik didasarkan pada keunggulan pendekatan tersebut. Beberapa tujuan pembelajaran dengan pendekatan saintifik adalah sebagai berikut:

a. Untuk meningkatkan kemampuan intelek, khususnya keterampilan berpikir tingkat tinggi siswa.

b. Untuk membentuk kemampuan siswa dalam menyelesaikan ustu masalah secara sistematik.

c. Terciptanya kondisi pembelajaran dimana siswa merasa bahwa belajar itu merupakan suatu kebutuhan.

d. Diperolehnya hasil belajar yang tinggi.

e. Untuk melatih siswa dalam mengomunikasikan ide-ide, khususnya dalam menulis artikel ilmiah.

f. Untuk mengembangkan karakter siswa. (Hosnan, 2014:36).

\section{Langkah-Langkah Pembelajaran dengan Pendekatan Saintifik.}

Langkah-langkah pendekatan ilmiah (Scientififc Approach) dalam proses pembelajaran meliputi: menggali informasi melalui observing/pengamatan, questionin atau bertanya, experimenting atau percobaan, kemudian mengolah data atau informasi, menyajikan data atau informasi, 
dilanjutkan dengan menganalisis, associating atau menalar, kemudian menyimpulkan, dan mencipta serta membentuk jaringan atau networking.

\section{Pembelajaran Berbasis Masalah (Problem Based Learning)}

Problem based learning (PBL) merupakan pembelajaran yang penyampaiannya dilakukan dengan cara menyajikan suatu permasalahan, mengajukan pertanyaan-pertanyaan, memfasilitasi penyelidikan, dan membuka dialog. Permasalahan yang dikaji hendaknya merupakan permasalahan kontekstual yang ditemukan oleh peserta didik dalam kehidupan sehari-hari. Permasalahan harus dipecahkan dengan menerapkan beberapa konsep dan prinsip yang secara simultan dipelajari dan tercakup dalam kurikulum mata pelajaran. Sebuah permasalahan pada umumnya diselesaikan dalam beberapa kali pertemuan karena merupakan permasalahan multikonsep, bahkan dapat merupakan masalah multidisiplin ilmu.

\section{Model Pembelajaran PBL}

Menurut Sani (2014:157) model PBL yang telah dikembangkan dengan sintak belajar terdiri dari beberapa fase, diantaranya sebagai berikut:

a. Memberikan orientasi masalah

b. Mengembangkan dan menyajikan

c. Menganalisis dan mengevaluasi proses penyelidikan.

\section{Pembelajaran Berbasis Proyek (Project Based Learing)}

Project Based Learning (PjBL) pada umumnya terkait dengan pembahasan permasalahan nyata, seperti dinyatakan dalam panduan $\mathrm{PjBL}$ Departemen Pendidikan New York (2009). PjBL Connects to real world and authentic problems and issues. (Sani, 2014:171).

Sementara itu, menurut Patton (2012), PjBL harus melibatkan siswa dalam membuat proyek atau produk yang akan dipamerkan pada masyarakat.
"Project-based learning refers to students designing, planning, and carrying out an extended project that produces a publicly-exhibited output such as a product, publication, or presentation"

Beberapa ahli mengusulkan beberapa tahapan utama yang perlu dilakukan dalam PjBL, yaitu

a. Mengajukan pertanyaan

b. Membuat perencanaan

c. Menyusun penjadwalan

d. Memonitor pembuatan proyek

e. Melakukan penilaian

f. Evaluasi. (Sani, 2014:180).

\section{METODELOGI PENELITIAN Rancangan Penelitian}

Pada penelitian ini peneliti menggunakan penelitian eksperimen. Penelitian eksperimen dilakukan karena peneliti akan mengujicobakan penelitiaanya ke dalam tiga kelas, yaitu dengan menerapkan model pembelajaran PBL, model pembelajaran PJBL dan model pembelajaran konvensional.

\section{Pembuatan Perangkat Pembelajaran}

Sebelum penelitian ini diterapkan pada kelompok eksperimen, maka peneliti membuat beberapa perangkat pembelajaran $\mathrm{PBL}$ dan PjBL pada kelompok uji coba. Untuk pembuatan perangkat pembelajaran meliputi: Rencana Pembelajaran (RP), Kuis dan Tes Hasil Belajar (THB.

Sebelum uji coba, dilakukan terlebih dahulu uji keterbacaan terhadap Draft II. Hal itu dilakukan untuk melihat apakah perangkat pembelajaran dapat terbaca dengan jelas dan dapat dipahami oleh mahasiswa. Subjek penelitian pada uji keterbacaan adalah 3 orang di kelas A Jurusan PGSD Unipa. Keempat orang tersebut diambil dari kelas yang tidak digunakan untuk kelas uji coba, kelas eksperimen ataupun kelas kontrol dalam penelitian. Masukan yang diperoleh dari hasil uji keterbacaan digunakan untuk merevisi Draft II, sehingga dihasilkan Draft III yang akan digunakan untuk uji coba.. 


\begin{abstract}
Uji coba dilakukan untuk memperoleh masukan langsung pengamat (observer) terhadap perangkat pembelajaran dan instrumen penelitian yang telah disusun. Hasil uji coba dalam pengembangan ini dijadikan dasar untuk penyempurnaan Draft IV menjadi Draft yang siap dieksperimenkan. Untuk uji coba dilaksanakan di kelas A PGSD Unipa Surabaya tahun 2014/2015 dengan memilih salah satu kelas secara acak dari empat kelas pararel yang berkemampuan setara.
\end{abstract}

\section{Sampel Penelitian}

Uji coba dilaksanakan pada Jurusan PGSD Unipa tahun 2014/2015 dengan memilih satu kelas secara acak dari empat kelas paralel yang berkemampuan setara. Untuk mengetahui kemampuan peserta didik agar setara peneliti meminta saran dari ketua program studi atau pendidik yang bersangkutan.

\section{Instrumen Penelitian Uji Coba}

Dalam rangka mengumpulkan data uji coba, peneliti membuat instrumen THB dikembangkan sendiri oleh peneliti. Tes dalam penelitian ini berupa tes pilihan ganda. THB diberikan kepada peserta didik sebanyak dua kali yaitu sebelum dan sesudah dimulai pokok bahasan HAM. Tujuan dilakukanya tes dimaksudkan untuk mengetahui perbedaan hasil belajar peserta didik sebelum dan sesudah pembelajaran.

\section{Uji Validitas dan Reliabilitas Perangkat Pembelajaran a. Uji Validitas}

Uji validitas dilakukan untuk menguji apakah perangkat penelitian ini telah mengukur apa yang seharusnya diukur. Untuk menguji agar tes hasil belajar (THB) valid, peneliti melakukan analisis validasi butir soal.

\section{b. Uji Reliabilitas Tes Hasil Belajar (THB) \\ Uji reliabilitas dilakukan untuk menguji keajegan atau konsistensi}

perangkat pembelajaran. Dalam penelitian ini, uji reliabilitas meliputi: tes hasil belajar (THB).

\section{Rancangan Penelitian Peneltian ini menggunakan desain Randomized Control Group Pretest-Postest Desaing.}

\section{Teknik Analisis Data Eksperimen}

Pada penelitian ini digunakan dua teknik analisis data, yaitu analisis statistik deskriptif dan analisis statistik inferensial.

Pada penelitian ini menggunakan statistik parametris karena telah memenuhi asumsi keparametrikan diantaranya:

1. Data berdistribusi normal.

2. Data homogen.

Sehingga uji beda yang dipakai dalam penelitian ini adalah uji-t. Penghitungan uji-t dilakukan dengan bantuan program SPSS versi 17.0 for windows.

\section{HASIL PENELITIAN Hasil Uji Homogenitas dan Normalitas}

Sebelum melakukan penelitian, terlebih dahulu peneliti menguji homogenitas dan normalitas mahasiswa PGSD Unipa Surabaya pada angkatan 2015 kelas A, kelas B dan kelas C. Tujuan uji homogenitas dan normalitas untuk mengetahui kemampuan awal mahasiswa, apakah kemampuan mahasiswa setara atau tidak.

Dari hasil analisis disimpulkan bahwa jumlah mahasiswa pada kelas A sebanyak 40 orang dan kelas B sebanyak 40 orang. Sedangkan pada kelas C berjumlah 41 orang. Nilai minimum yang diperoleh kelas A sebesar 30 dan kelas B sebesar 60, sedangkan pada kelas C sebesar 50. Nilai maksimum yang diperoleh kelas A sebesar 95 dan kelas B sebesar 99, sedangkan pada kelas C sebesar 90. Nilai rata-rata pada kelas A sebesar 72.5500 pada kelas B sebesar 72.56, dan pada kelas D sebesar 73.94. Besaran standar deviasi pada kelas A 
adalah 6.59662, kelas B 78.8000 dan kelas C 10.60073.

Sedagkan pada estimasi parameter diribusi menunjukkan bahwa ketiga kelas tersebut berada dalam distribusi normal. Perinciannya sebagai berikut, nilai pada kelas A sebesar 72.5500 dalam skala 10.95901, untuk kelas B nilainya sebesar 78.8000 dalam skala 9.54396, dan kelas C nilainya sebesar 73.9474 dalam skala 10.60073. Sehingga kesimpulannya, ketiga kelas tersebut homogen, artinya siswa pada kelas A, kelas B dan kelas C memiliki kemampuan yang sama. Penjelasan homogenitas ini juga dapat dilihat pada grafik masing-masing kelas dibawah ini. Dalam tiap grafik tampak data mengumpul pada sekitar garis, tidak menyebar, sehingga datanya dapat dikatakan homogen.

\section{Deskriptif Hasil Pembuatan Perangkat Pembelajaran \\ $\begin{array}{lcrr}\text { Pada } & \text { penelitian } & \text { ini } & \text { peneliti } \\ \text { membuat } & \text { beberapa } & \text { perangkat } \\ \text { pembelajaran } & \text { PBL } & \text { dan } & \text { PjBL, } \\ \text { diantaranya } & \text { adalah } & \text { Rencana }\end{array}$ Pembelajaran (RPP), Kuis dan Tes Hasil Belajar (THB). Sebelum diujicobakan peneliti meminta masukan dan saran ke validator untuk melakukan validasi terhadap RP, Kuis dan THB. Untuk hasil validasi oleh validator akan dijelaskan sebagai berikut:}

\section{a. Hasil Validasi Ahli}

Pada validasi para ahli difokuskan pada format, isi, ilustrasi, dan bahasa yang mencakup semua perangkat pembelajaran yang dikembangkan. Hasil validasi ahli berupa koreksi, kritik dan saran yang digunakan sebagai dasar untuk melakukan revisi dan penyempurnaan terhadap perangkat pembelajaran.

\section{b. Validator}

Validator yang melakukan validasi terhadap perangkat pembelajaran terdiri dari 2 orang yaitu 1 orang yang bergelar S-2 dari Jurusan Bahasa Indonesia dan 1 orang yang bergelar S-2 dari Jurusan PGSD. Nama- nama validator dapat dilihat pada lampiran

\section{Hasil Validasi Rencana Pembelajaran} (RP)

Berdasarkan penilaian para validator diperoleh koreksi, kritik dan saran yang digunakan sebagai bahan pertimbangan dalam melakukan revisi RP. Untuk saran perbaikan beberapa kesalahan penulisan dan ejaan pada naskah telah diperbaiki sesuai dengan coretan validator sedangkan revisi yang lainnya dapat dilihat pada tabel berikut:

\section{c. Hasil Validasi Kuis}

Hasil validasi kuis dari para validator pada umumnya menyimpulkan kuis ini baik dan dapat digunakan dengan sedikit revisi. Revisi yang dilakukan dapat dilihat pada tabel berikut.

\section{d. Hasil Validasi Tes Hasil Belajar (THB)}

Hasil validasi THB dari para validator pada umumnya menyimpulkan THB ini baik dan dapat digunakan dengan sedikit revisi. Dari beberapa penilaian di atas, secara umum hasil validasi para ahli terhadap perangkat pembelajaran adalah sebagai berikut :

1) Rencana pembelajaran mempunyai kategori baik dan dapat digunakan dengan sedikit revisi.

2) Lembar kegiatan mahasiswa mempunyai kategori cukup baik dan dapat digunakan dengan sedikit revisi.

3) Kuis mempunyai kategori baik dan dapat digunakan dengan sedikit revisi

4) Tes hasil belajar mempunyai kategori valid, dapat dipahami dengan sedikit revisi.

\section{Uji Coba Perangkat Pembelajaran}

Uji coba dilakukan untuk menyempurnaan perangkat pembelajaran sebelum perangkat pembelajaran digunakan pada kelas eksperimen. Uji coba dilaksanakan 2 kali pertemuan, sesuai dengan rencana pembelajaran di kelas. Untuk pelasanaan uji coba perangkat pembelajaran dilakukan di kelas 2014 A .

Dalam uji coba perangkat pembelajaran peneliti hanya 
mengujicobakan Tes Hasil Belajar (THB) yang diberikan sebelum dan sesudah pembelajaran. Hasil yang diperoleh sebagai berikut:

\section{a. Hasil Ujicoba Butir Soal}

Ujicoba tes hasil belajar dilakukan untuk mendapatkan data mengenai validitas butir tes dan reliabilitas tes. Untuk menentukan butir soal yang valid maka dilakukan perbandingan antara $r_{x y}$ hitung dengan $r$ tabel ( $\mathrm{r}$ tabel ditentukan dari dari tabel $\mathrm{r}$ dengan melihat nilai signifikansi $5 \%$ dan sesuai dengan jumlah subjek penelitian). Jika $r_{x y}$ lebih besar dari $r$ tabel, maka butir soal tersebut dapat dinyatakan valid. Dan sebaliknya, Jika $r_{x y}$ lebih kecil dari $r$ tabel, maka butir soal tersebut dapat dinyatakan tidak valid. Nilai $r$ tabel dalam penelitian ini adalah 0,404 (untuk signifikansi sebesar 5\%).

Berdasarkan rumus korelasi product moment, diperoleh validitas tiap butir tes sebagai berikut:20 butir yaitu di nomor. 2, 3, 4, 8, 9,10, 11, 14, 17,19, 27, 30, 32, 34, 38, 40, 41, 43, 44, 47. Sehingga dapat disimpulkan bahwa dalam penelitian ini peneliti menggunakan 20 butir soal untuk melakukan pretest dan posttest.

\section{Hasil Pretes - Postest}

Pada pelaksanaan pretes siswa kelas A diikuti oleh 30 orang, sedangkan pelaksanaan pretes siswa kelas siswa kelas $\mathrm{C}$ berjumlah 36 orang. Untuk hasil rata-rata pelaksanaan pretest kelas A sebesar 58.80, sedangkan pelaksanaan pretest kelas $\mathrm{C}$ sebesar 50.30. Sementara itu untuk pelaksanaan posttest kelas A, nilai rata-rata sebesar 84.16 , sedangkan untuk pelaksanaan posttest kelas $\mathrm{C}$ nilai rata-rata sebesar 90.55 .

\section{Hubungan PBL dengan PjBL}

Dari hasil pretest dan postest yang dilakukan dua kelas menunjukkan bahwa ada perbedaan hasil belajar dengan menggunakan model pembelajaran PBL dan PjBL. Untuk hasilnya sebagai berikut:
Dari data diatas dapat disimpulkan bahwa penerapan model PjBL pada kelas C memiliki nilai korelasi yang lebih tinggi dibandingkan penerapan model PBL pada kelas A. Hal ini dapat dilihat dari koefisien korelasi sampel kelas C yang bernilai 0.676 dan koefisien korelasi kelas A bernilai 0.42. Selain itu untuk signifikansinya juga lebih tinggi pada sampel kelas $C$ yang bernilai 0.000 dibanding signifikansi kelas A yang bernilai 0.021 .

\section{KESIMPULAN}

Dari hasil penelitian ini dapat disimpulkan terdapat ada perbedaan hasil belajar antara model PBL dengan PjBL. Jadi pada penelitian ini hipotesis diterima dengan asumsi Ho ditolak dan $\mathrm{Ha}$ diterima.

\section{DAFTAR PUSTAKA}

Arikunto, Suharsimi. 2005. Prosedur Penelitian: Suatu Pendekatan Praktik. Jakarta: Rineka Cipta.

Hosnan, M. 2014. Pendekatan Saintifik Dan Kontekstual Dalam Pembelajaran Abad 21. Bogor: Ghalia Indonesia.

Rahayu, Ani Sri. 2013. Pendidikan Pancasila dan Kewargenagaraan (PKn). Jakarta: Bumi Aksara

Sani, Ridwan Abdullah. 2014.

Pembelajaran Saitifik. Jakarta:

Bumi Aksara.

Sigiyono. 2008. Statistika Untuk Penelitian. Bandung: Alfabeta.

Winataputra, Udin. 2014.

Pembelajaran PKn di SD.

Tanggerang Selatan: Universitas

Terbuka. 